\title{
EFEKTIFITAS LAMA PERENDAMAN KELAMBU DAN MERK INSEKTISIDA TERHADAP KEMAMPUAN DAYA BUNUH NYAMUK Anopheles Spp TAHUN 2015
}

\author{
Maharani Cahyaningtiyas ${ }^{1)}$, Aris Santjaka ${ }^{2)}$ \\ Jurusan Kesehatan Lingkungan, Politeknik Kesehatan Kemenkes Semarang, \\ Jl. Raya Baturraden KM 12 Purwokerto, Indonesia.
}

\begin{abstract}
Abstrak
Nyamuk Anopheles Spp merupakan satu-satunya vektor penular penyakit malaria.Upaya pengendalian nyamuk Anopheles Spp salah satunya dengan menggunakan insektisida berupa kelambunisasi.Tujuan penelitian ini mengetahui pengaruh lama perendaman dan merk insektisida.Jenis penelitian yang dipilih eksperimen dengan kualifikasi true experimental design dengan desain penelitian the posttest-only control group design.Uji statistik digunakan Block Anova kemudian dilanjutkan dengan uji LSD (Least Significant Difference).Hasil penelitian menunjukkan rata-rata kematian nyamuk pada Merk Insektisida $B, H, V$ dan kontrol secara berturut-turut yaitu $18,75,19,25,18,75$ dan 2,75. Rata-rata kematian nyamuk pada lama perendaman 15', 30', 45' dan 60' secara berturut-turut yaitu 16,3, 20, 20 dan 19,3 ekor. Hasil signifikasi menunjukan nilai 0,006<a $(0,05)$ untuk lama perendaman sehingga Ho ditolak artinya ada perbedaan lama perendaman dan nilai 0,670> $\alpha(0,05)$ untuk Merk Insektisida sehingga Ho diterima artinya tidak ada pengaruh Merk Insektisida terhadap kematian nyamuk Anopheles Spp.Hasil penelitian dapat disimpulkan suhu dan kelembaban nyaman untuk nyamuk. Ada perbedaan lama perendaman kelambu yaitu antara lama perendaman 15,30',45' dan 60' terhadap kematian nyamuk Anopheles Spp. Tidak ada perbedaan Merk Insektisida B, H, dan V. Sehingga kemampuan tertinggi daya bunuh nyamuk pada perendaman 30' dan Merk Insektisida $H$.
\end{abstract}

Kata kunci :Anopheles Spp, lama perendaman, merk insektisida

\begin{abstract}
Anopheles Spp mosquito was the only malaria disease vector. It controlling was conducted by using insecticides in the form of netting. The objective was investigating the effect of net soaking time and insecticides brand.The research method used was experimental design with true experimental with design through posttest-only control group design. The statistical test used was Block Anova test continued with LSD (Least Significant Difference).The research results shows that the average mosquitoes mortality for Insecticides Brand $B, H, V$ and control respectively are 18.75, 19.25, 18.75 and 2.75. Average mosquitoes mortality based soaking time 15 ', 30', 45 'and 60 ' respectively are 16.3, 20, 20 and 19.3. the statistical test Results obtained $p$ value $0.006<\alpha(0.05)$ for soaking time so that Ho was rejected that mean there was significant difference based soaking time and obtained pvalue 0.670> $\alpha(0,05)$ for Insecticides Brand so Ho was accepted, that mean there was no Insecticides Brand effect on Anopheles Spp mosquito mortality, The conclusion drawn was; temperature and humidity comfortable for mosquitoes. There was significant difference between net soaking time 15',30', 45 'and 60' to the Anopheles Spp mortality. There was no significant difference between Insecticides Brand $B, H$, and $V$. The highest mosquitoes killing power was soaking for $30^{\prime}$ and insecticide brand $H$
\end{abstract}

Key word: Anopheles Spp, soaking time, insecticide brand

\section{PENDAhuluan}

Penyakit malaria ditularkan oleh nyamuk dari species Anopheles yang menginjeksikan sporosit yang berbentuk infektif, parasit malaria yang berasal dari nyamuk penular kepada manusia (vektor manusia). Nyamuk dalam siklus hidupnya memerlukan tempat perindukan ,tempat perindukan nyamuk Anopheles Spp adalah genangan-genangan air di selokan, sawah, rawa-rawa atau di saluran irigasi yang aliran airnya tenang. Nyamuk pada umumnya mempunyai empat stadium dalam perkembangannya yaitu telur, larva, pupa dan dewasa.Stadium telur, larva, pupa berada di dalam air serta disebut pra dewasa, sedangkan nyamuk dewasa hidup di lingkungan luar air.

Indonesia dengan lingkungan yang terdiri dari daerah sawah, semak belukar yang rindang dan rawarawa serta air yang tenang merupakan daerah yang sangat cocok untuk tempat perindukan nyamuk 
Anopheles Spp sebagai vektor malaria.Salah satu kasus malaria terdapat di Provinsi Jawa Tengah.

Upaya pemberantasan yang dapat dilakukan adalah menekan densitas vektor, sehingga risiko penularan Plasmodium fase gamet dapat ditekan seminimal mungkin, upaya yang dilakukan dengan cara penyemprotan insektisida dan pemakaian kelambu yang terbuat dari bahan yang sudah dicampur dengan insektisida yaitu Long Lasting insecticide Nets (LLi'Ns).

Pemakaian LLi'Ns ini dilakukan oleh pemerintah, sayangnya harga kelambu tersebut sangat mahal untuk ukuran masyarakat desa yang mayoritas petani dan buruh tani dengan lahan yang sangat terbatas dan tinggal di daerah terisolir karena kasus malaria sering terjadi di daerah remote area.Harga satu kelambu untuk ukuran satu bed tempat tidur Rp 200.000 (dua ratus ribu rupiah) dan kelambu ini tidak dijual bebas.Sehingga kelambu ini hanya diberikan di daerah khusus terutama daerah KLB.

Masyarakat sebenarnya mampu untuk membeli kelambu dari kain untuk tempat tidurnya, namun kelambu tersebut belum berinsektisida. Keterbatasan anggaran pemerintah dalam pengadaan kelambu LLi'Ns karena mahal dan kemampuan terbatas masyarakat untuk membeli kelambu, maka peneliti memberi solusi yaitu pengadaan kelambu berinsektisida, kelambu tersebut merupakan kelambu yang ada akan direndam dalam insektisida yang ada di masyarakat seperti merk B, H dan V.

Tujuan penelitian ini adalah mengetahui pengaruh lama perendaman dan merk insektisida terhadap kematian nyamuk Anopheles Spp.

\section{BAHAN DAN METODE}

Penelitian ini termasuk jenis penelitian eksperimen dengan kualifikasi true experimental design.Desain penelitian yang dipilih the posttestonly control group design yaitu salah satu disain penelitian eksperimen yang membandingkan hasil eksperimen antara kelompok perlakuan dan kelompok kontrol.

Populasi dalam penelitian ini adalah seluruh nyamuk Anopheles Spp dan sampel yang digunakan adalah nyamuk Anopheles Spp yang didapatkan secara random sebanyak 20 ekor pada tiap kelambu.

Uji statistik yang digunakan adalah uji Block Anova dan dilanjutkan dengan uji LSD (Least Significant Difference).

\section{III.HASIL DAN PEMBAHASAN}

Hasil rata-rata kematian nyamuk Anopheles Spp berdasarkan lama perendaman yaitu pada lama perendaman $15^{\prime}, 30^{\prime}, 45^{\prime}$ dan 60' secara berturutturut yaitu 16,3 ekor (81,6\%), 20 ekor (100\%), 20 ekor $(100 \%)$ dan 19,3 ekor (96,6\%). Hasil kematian nyamuk paling tinggi terdapat pada lama perendaan 30 ' dan $45^{\prime}$ dengan rata-rata kematian nyamuk sebesar $100 \%$. Pada lama perendaman 30 menit kelambu sudah cukup jenuh sehingga bahan aktif insektisida yang terserap kelambu dapat mematikan nyamuk Anopheles Spp.

Hasil pengamatan dan perhitungan rata-rata jumlah nyamuk Anopheles Spp yang mati berdasarkan merk insektisida, Pada merk insektisida $\mathrm{H}$ rata-rata kematian nyamuk adalah 19,25 ekor $(96,25 \%)$ dan pada merk insektisida $\mathrm{V}$ rata-rata kematian nyamuk adalah 18,75 ekor $(93,75 \%)$ serta pada kontrol rata-rata kematian nyamuk adalah 2,75 ekor $(13,73 \%)$. Hasil rata-rata kematian nyamuk berdasarkan merk insektisida, semua merk insektisida mendapatkan nilai rata-rata kematian nyamuk antara 80-98\% artinya semua merk insektisida yang digunakan dalam penelitian masih bisa digunakan tetapi harus ada peningkatan dosis.

Suhu ruangan diukur menggunakan thermometer ruangan, pengukuran dilakukan pada saat pengamatan selama 30 menit. Hasil pengukuran suhu adalah $26,8^{\circ} \mathrm{C}$, suhu tersebut relatif cocok untuk perkembangan nyamuk.Suhu ruangan yang optimum untuk perkembangan nyamuk adalah $25^{\circ}$ $27^{\circ} \mathrm{C}$.Nyamuk termasuk binatang berdarah dingin sehingga metabolisme dan siklus kehidupannya tergantung pada suhu lingkungan, sehingga pengaturan suhu tubuh sangat tergantung pada pengaturan lingkungannya. Pada suhu kurang dari $16^{\circ} \mathrm{C}$ dan lebih tinggi dari $32^{\circ} \mathrm{C}$ nyamuk akan mengalami gangguan pertumbuhannya, suhu optimum pertumbuhan nyamuk adalah $25^{\circ}-27^{\circ} \mathrm{C}$. perubahan suhu sangat berpengaruh pada nyamuk, secara umum perubahan antara $5^{\circ} \mathrm{C}-6^{\circ} \mathrm{C}$ nyamuk tidak tahan hidup dan akan mengalami kesulitan beradaptasi.

Kelembaban udara diukur menggunakan hygrometer, pengukuran dilakukan pada saat pengamatan selama 30 menit.Hasil pengukuran kelembaban udara ruang penelitian sebesar $84 \%$, hasil tersebut sangat cocok untuk perkembangan nyamuk. Pada kelembaban rendah terjadi penguapan tinggi pada tubuh nyamuk, karena mekanisme pengaturan penguapan tidak terjadi, dampaknya nyamuk akan kehilangan cairan cukup besar, sehingga mengalami kekeringan cairan.

Variabel independen yang di uji adalah lama perendaman dan merk insektisida, dari tabel signifikasi variabel lama perendaman mendapat nilai signifikasi $<\alpha(0,05)$ yaitu nilai $\mathrm{p}=0,006$ dan variabel merk insektisida mendapat nilai signifikan $>\alpha(0,05)$ yaitu nilai $\mathrm{p}=0,670$.

Hasil uji Block Anova menunjukkan nilai signifikan 0,006 untuk lama perendaman yang berarti nilai signifikan $<\alpha(0,05)$. Hasil tersebut menunjukan bahwa Ho ditolak artinya ada perbedaan lama perendaman kelambu terhadap kematian nyamuk Anopheles Spp. Lama perendaman kelambu yang digunakan dalam penelitian ini adalah lama perendaman 15', 30', 45' dan 60' perbedaan lama perendaman tersebut dikarenakan kelambu yang berbahan kain bersifat absorbsi, semakin lama direndam kelambu tersebut akan semakin jenuh. 
Lama perendaman tersebut juga dimaksudkan untuk memberikan kesempatan kepada bahan aktif insektisida menyerap kedalam kelambu yang berbahan kain.

Nilai signifikan menunjukkan nilai 0,670 untuk merk insektisida yang berarti $>\alpha(0,05)$. Hasil tersebut menunjukan bahwa Ho diterima artinya tidak ada perbedaan merk insektisida terhadap kematian nyamuk Anopheles Spp, hal tersebut menunjukkan bahwa semua merk insektisida mempunyai daya bunuh yang sama terhadap nyamuk Anopheles Spp.

Hasil analisis dilanjutkan menggunakan uji LSD (Least Signifficant Difference) untuk mengetahui perbedaan lama perendaman 15 menit, 30 menit, 45 menit dan 60 menit serta mengetahui perbedaan merk insektisida $\mathrm{B}, \mathrm{H}$ dan $\mathrm{V}$.

Berdasarkan uji LSD dapat disimpulkan bahwa ada perbedaan lama perendaman 15 menit dengan lama perendaman 30 menit, 45 menit dan 60 menit serta lama perendaman 30 menit dengan lama perendaman 15 menit. Tidak ada perbedaan merk insektisida $\mathrm{B}, \mathrm{H}$ dan $\mathrm{V}$.

Hasil analisis dapat disimpulkan lama perendaman paling efektif adalah lama perendaman kelambu 30' karena pada waktu tersebut cukup untuk mebuat kelambu jenuh, sedangkan merk insektisida yang paling efektif untuk mematikan nyamuk Anopheles Spp adalah merk insektisida H, bahan aktif yang terkandung dalam merk insektisida $\mathrm{H}$ adalah transflutrin yang merupakan senyawa atau racun sintesis.

\section{IV.SIMPULAN}

Kondisi lingkungan nyaman untuk kelangsungan hidup nyamuk Anopheles Spp dengan suhu $26,8^{\circ} \mathrm{C}$ dan kelembaban $84 \%$. Jumlah kematian nyamuk Anopheles Spp berdasarkan lama perendaman paling tinggi terdapat pada lama perendaman 30 menit dan 45 menit dengan rata-rata kematian sebanyak 20 ekor dan jumlah kematian nyamuk Anopheles Spp paling rendah terdapatpada lama perendaman 15 menit ratarata 16,3 ekor. Merk insektisida $\mathrm{H}$ memiliki rata-rata kematian nyamuk paling tinggi yaitu 19,25 ekor. Jumlah kematian nyamuk Anopheles Spp berdasarkan merk insektisida paling tinggi terdapat pada merk insektisida $\mathrm{H}$ dengan rata-rata kematian nyamuk 19,25 ekor dan kematian nyamuk Anopheles Spp paling rendah terdapat pada merk insektisida V dengan rata-rata kematian nyamuk 18,75 ekor.

\section{DAFTAR PUSTAKA}

Cahyono, Tri. (2014).Pedoman Penulisan Proposal Penelitian dan Karya Tulis Ilmiah/Skripsi Edisi Revisi Ketiga.Purwokerto : Kementrian Kesehatan RI Politeknik Kesehatan Jurusan Kesehatan Lingkungan Purwokerto.

Chasan S, Kusnadi. (2006). Pengendalian Vektor dan Binatang Pengganggu.Makassar : Instalasi
Penerbitan Jurusan Kesehatan Lingkungan Poltekkes Makassar.

Departemen Kesehatan Republik Indonesia.(2007). Survey Entomologi Malaria. Direktorat Jendral Pemberantasan Penyakit dan Penyehatan Lingkungan Pemukiman. Jakarta.

Departemen Kesehatan Republik

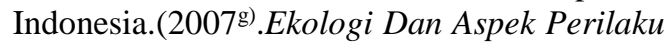
Vektor, Direktorat Jendral Pemberantasan Penyakit Menular Dan Penyehatan Lingkungan Pemukiman : Jakarta

Departemen Kesehatan Republik Indonesia. (2008). Pedoman Penatalaksanaan Kasus Malaria di Indonesia. Direktorat Jendral Pemberantasan Penyakit Menular dan Penyehatan Lingkungan Permukiman : Jakarta

Edbas.(2010)Fisiologi serangga. Universitas Jendral Soedirman : Purwokerto

Elyes DE, Wharton $\mathrm{H}$, Cheong $\mathrm{H}$ \& Wharen $\mathrm{M}$. (1964).Studies on Malaria balabacensis in Camboja, WHO.Phom. Cambodia

Harijanto PN, Nugroho A \& Gunawan CA, (2010).Malaria dari molekuler ke klinis,Penerbit buku kedokteran EGC : Jakarta

Sanovi Aventis, Effect of environmental on mosquito life cycle. http://en.impact-malaria.com. Akses tanggal 5 Juli 2015

Santjaka, A.(2008).Statistik Untuk Penelitian Kesehatan. Nuha Medika : Yogyakarta.

Santjaka, A(2013). Malaria Pendekatan Metode Kausalitas. Nuha Medika : Yogyakarta.

Santjaka, A. (2014).Aplikasi SPSS untuk Data Penelitian Kesehatan. Nuha Medika : Yogyakarta.

Sari, L.K, Safni dan Zalfa.(2012).Degadasi Senyawa Sipermetrin dalam Insektisida Ripcord 5 ECsecara Fotolisis dengan Penambahan Tio2/Zeolit. Jurnal Kimia Unand.Volume 1 Nomor 1 hal :76-81.

Sudarto. (2003). Zoonosis Kedokteran. Cetakan I. Universitas Airlangga : Surabaya

Sudarto. (2008).Parasitologi Klinik,. Universitas Airlangga : Surabaya.

Sudarto.(2011). Malaria. Sagung Seto : Jakarta. 